\title{
Analisis Sistem Informasi Pada Padiciti Menggunakan Konsep Competitive Forces and Strategy
}

\author{
Vivi Kusuma Hertantri ${ }^{1)}$ \\ ${ }^{1)}$ Pendidikan Teknik Informatika Universitas Negeri Yogyakarta \\ vivy.kh.13@gmail.com
}

\begin{abstract}
ABSTRAK
Perkembangan sistem informasi mendukung dalam menyediakan tiket secara online dan realtime. E-commerce merupakan proses bisnis yang menggunakan internet dalam menjalankannya. Padiciti merupakan salah satu e-commerse yang menyediakan aplikasi pemesanan tiket kereta api, tiket pesawat, dan hotel. Padiciti dapat diakses melalui aplikasi smartphone dan website yang terintegrasi. Tujuan paper ini adalah untuk menganalisis sistem informasi Padiciti menggunakan metode dengan konsep Competitive Forces and Strategy. Hasil analisis menunjukkan bahwa Padiciti telah dapat menjadi sistem informasi yang sesuai dengan Competitive Forces and Strategy dengan hasil yang baik dan dapat bertahan dengan kelebihan dan kekuatan yang kompetitif. Kekuatan Padiciti terdapat pada aspek Cost Leadership, Differentiation, Innovation, Growth, Alliance, Other Strategies, Threat of New Entrants, Bargaining Power of Customers, Bargaining Power of Suppliers dan kelemahan Padiciti terdapat pada aspek Rivalvy of Competitors dan Threat of Substitute.
\end{abstract}

Kata kunci: Analisis Sistem, Competitive Forces and Strategy, E-Commerce, Padiciti

\section{PENDAHULUAN}

Tiket telah tersedia dalam berbagai bentuk penjualan yang memudahkan pelanggan dalam mendapatkan tiket secara cepat. Dalam proses jual beli, kini telah banyak digunakan ecommerce. E-Commerce menggunakan internet sebagai media dalam proses bisnis mulai dari proses pemasaran, penjualan dan juga pembelian suatu produk. Perkembangan sistem informasi mendukung dalam menyediakan tiket mulai dari kereta api, pesawat dan hotel yang terhubung baik lokal maupun internasional secara online dan realtime. Penyediaan tiket secara online berdampak pada mudahnya dalam mengakses kapan pun dan dimana pun. Realtime memudahkan pelanggan dalam mendapatkan infomasi yang akurat dalam satuan detik. Hal tersebut perlu bagi calon pembeli tiket sebelum mendapatkan tiket sesuai kebutuhan.

Beberapa pengelola industri telah memiliki sistem informasi masing-masing dalam menyediakan ketersediaan tiket. Hal tersebut memiliki kelebihan dan kekurangan. Kelebihan dapat dirasakan jika pelanggan sudah memiliki tujuan armada yang akan dipilih, sedangkan kekurangan pada saat pelanggan belum menetapkan armada yang dipilih untuk mengakomodasi perjalanan yang akan dilakukan. Kekurangan tersebut dapat diatasi oleh sistem penyediaan tiket yang terintegrasi, sehingga dapat memberikan alternatif yang cukup banyak kepada pelanggan. Hal tersebut didukung dengan partner perjalanan yang semakin banyak.

Sistem informasi penyedia layanan tiket terintegrasi telah banyak disediakan di Indonesia. Sistem informasi yang terintegrasi memiliki kerjasama dengan partner yang memiliki layanan jasa transportasi darat maupun udara serta akomodasi penginapan berupa hotel. Sistem informasi tersebut dapat diakses melalui website pada desktop dan juga aplikasi berbasis mobile pada smartphone yang dapat diunduh pada masing-masing layanan penyedia aplikasi. Salah satu sistem informasi yang menyediakan layanan tiket terintegrasi adalah Padiciti.

Padiciti merupakan aplikasi pemesanan tiket kereta api, tiket pesawat, dan hotel. Saat ini, Padiciti memiliki 300.000 lebih pelanggan. Padiciti terhubung secara host-to-host dengan PT Kereta Api Indonesia. Penggunaan fiber optic membuat layanan penjualan tiket menjadi handal dan reliabel. Padiciti dapat diakses 
melalui aplikasi smartphone dan juga website. Aplikasi Padiciti terhubung di seluruh platform yang dapat di download pada Google Play untuk Android, AppStore untuk iOS, WindowsStore untuk Windows, dan AppWorld untuk BlackBerry.

Pada awalnya Padiciti hanya bergerak dalam penyedia tiket kereta api bernama Paditrain. Kemudian, pada perkembangannya Paditrain berubah nama menjadi Padiciti dengan penambahan layanan penyedia tiket pesawat dan hotel.

Padiciti menjual tiket pesawat berbagai maskapai. Padiciti juga menyediakan pemesanan kamar hotel yang terhubung ke lebih dari 80.000 hotel. Berikut ini Gambar 1 . menunjukkan partner perjalanan resmi Padiciti :

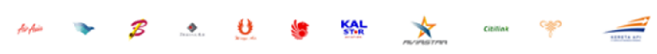

Gambar 1.partner perjalanan resmi Padiciti

Berbagai metode pembayaran disediakan untuk memudahkan pelanggan. Padiciti memberikan layanan customer service berupa telepon, email, website dan alamat kantor. Customer service merupakan hal terpenting dalam pelayanan konsumen, dimana masalah dapat teratasi dengan cepat dan mudah. Pengguna Padiciti adalah customer yang telah melakukan register dan dapat login setelah memiliki akun. Akun yang dimiliki dapat diakses pada website maupun aplikasi yang terdapat pada smartphone yang dimiliki oleh pelanggan.

Padiciti memberikan banyak kelebihan, diantaranya pre-order, waiting list, peta stasiun, jadwal kereta terkini, pilih kursi sendiri, pilihan maskapai terbaik, detail harga yang terbuka, cara bayar lengkap, padipay deposit dengan satu kali input. Saat melakukan order melalui website Padiciti, pesanan tiket juga tersinkronisasi dengan aplikasi android dan iOS yang dimiliki customer. Pemesanan tiket melalui Padiciti ditampilkan secara realtime dengan menjamin ketersediaan tiket. Sehingga memeberikan kelebihan dimana customer dapat memilih posisi tempat duduk yang sesuai keinginan. Selain itu, dapat dilakukan refund dengan mudah dan aman pada pembelian tiket maskapai penerbangan. Syarat dan ketentuan berlaku disesuaikan dengan peraturan yang dibuat oleh Padiciti dan partner perjalanan.

Kekurangan Padiciti terletak pada bagian customer service yang tidak melayani telepon 24 jam, dimana masalah pelanggan dapat terjadi kapan saja dan harus segera diselesaikan. Selain itu, dikarenakan pelayanan Padiciti bergantung pada internet, maka rentan terjadi kesalahan pembayaran menggunakan e-banking yang kehilangan sinyal, hal tersebut dapat berakibat tidak terkirimnya kode booking yang harus dicetak menjadi tiket sesungguhnya sebelum customer melakukan perjalanan.

Pesaing Padiciti diantarannya: Tiket.com, KAI Express, Traveloka, uTiket. Pesaing Padiciti memberikan layanan penyedia tiket yang terintegrasi dengan partner yang tidak sedikit. Hal tersebut dapat berpengaruh pada kekuatan kompetitif pada Padiciti. Selain itu juga dapat menjadi pertimbangan Padiciti dalam menentukan strategi bisnis agar tetap dapat bersaing dan bertahan dengan baik.

Paper ini bertujuan untuk menganalisis sistem informasi Padiciti menggunakn konsep Competitive Forces and Strategy. Sub bagian yang dianalisis meliputi Strategi Kompetitif dengan sub bagian : Pelopor biaya, Perbedaan, Inovasi Pertumbuhan, Aliansi, Strategi lain. Pada Kekuatan Kompetitif dengan sub bagian : Persaingan dengan Kompetitor, Ancaman Pendatang Baru, Ancaman Pengganti, Kekuatan Customer dan Kekuatan Supplier.

E-commerce merupakan bagian dari ebusiness yang pertama kali diperkenalkan pada tahun 1994. Sasaran e-commerce adalah menciptakan lingkungan komersial yang baru dalam era elektroni. E-commerce memiliki karakteristik yang khusus diantaranya: (a) Transaksi Tanpa Batas, produk dapat dipasarkan secara internasional dengan membuat website maupun menjadikan sebagai iklan-iklan pada situs internet tanpa adanya 
batas geografis dan juga waktu. (b) Transaksi Anonim, pada proses jual beli tidak perlu bertemu secara langsung, selama proses pembayaran telah dilakukan dengan otoritas penyedia layanan pembayaran yang telah ditentukan. (c) Produk Digital dan Non Digital, produk dapat berupa digital dan non digital. Produk digital berupa teks, suara, dan juga gambar. Produk non digital berupa produk fisik. (d) Produk Barang Tak Terwujud, produk dapat berupa barang tak terwujud seperti data, software dan berbagai ide-ide yang dijual melalui internet.

Kategori pada klasifikasi e-Commerce dibagi menjadi empat diantaranya adalah Business to Business (B2B), Business to Consumer (B2C), Consumer to Consumer (C2C), dan Consumer to Business (C2B).

Padiciti masuk dalam klasifikasi business to consumer (B2C) dalam e-commerce. Business to consumer merupakan situs web ecommerce yang melakukan kegiatan bisnis langsung dengan customer. B2C memiliki karakteristik diantaranya terbuka untuk umum dimana informasi disebarkan ke umum, servis yang diberikan bersifat umum yang dapat digunakan oleh khalayak ramai dengan berbasis web, dan service on demand, servis diberikan berdasarkan permintaan.

Purbo dan Wahyudi menyatakan keuntungan-keuntungan bagi perusahaan yang menggunakan e-commerce diantaranya adalah terbukanya aliran pendapatan baru yang lebih menjanjikan yang tidak didapatkan pada sistem transaksi tradisional, meningkatkan market exposure, menurunkan biaya operasional, melebarkan jangkauan, meningkatkan kesetiaan pelanggan, meningkatkan manajemen suplier, memperpendek waktu produksi, dan eningkatkan rantai nilai.

Pada penelitian Mintarsih, Bahawarez, \& Fauziah menggunakan five force competitionporter dalam menganalisis sistem menghasilkan informasi yakni pada proses perancangan, aspek ancaman pendatang baru dapat diatasi dengan beberapa hal berikut : loyalitas pelanggan, diferensiasi produk, akses ke saluran distribusi, kekuatan penawaran pembeli, ancaman produk atau jasa pengganti, kekuatan penawaran pemasok dan persaingan antara perusahaan yang ada. Hal tersebut menjadi acuan dalam merancang sistem yang dapat bertahan dalam persaingan bisnis. Perancangan dilakukan sebelum sistem informasi dikembangkan sehingga dapat menghasilkan sistem informasi yang berdaya saing tinggi dan dapat bertahan lebih baik dari para pesaingnya. Aspek ancaman dapat diminimalisir dengan strategi yang dirancang dalam mengembangkan sistem informasi.

Analisis Competitive Strategies telah dilakukan pada beberapa industri penerbangan dalam menyediakan tiket masing-masing armada. Dalam penelitian yang dilakukan oleh Kuntjoroadi \& Safitri membahas mengenai posisi bersaing (competitive positioning) Garuda terhadap persaingan dalam jasa penerbangan di Indonesia, termasuk didalamnya jasa penyedia layanan tiket yang dilakukan dengan promosi dan kerjasama penyedia tiket online dalam upaya memperkecil kompetitor (rivalty of competitors). Dalam penelitian tersebut dapat diketahui bahwa melalui media promosi, Garuda dapat memperkecil persaingan dengan sesama penyedia layanan pesawat terbang lainnya.

Analisis Strategis Web E-Commerce Dengan Metode Value Chain Analysis (Studi Kasus Pt. Sriwijaya Optimis Mandiri) oleh Rasmila menerangkan bahwa penjualan tiket secara online memberikan kemudahan kepada konsumen dalam memperoleh tiket pertandingan secara online dan juga membantu manajemen perusahaan untuk pengendalian dan pengawasan, selain itu juga dapat meningkatkan pendapatan keuangan perusahaan dari penjulanan tiket kepada konsumen yang selama ini di kelola oleh perusahaan pihak ketiga (vendor) yang di tunjuk oleh perusahaan untuk mengelola penjualan tiket pertandingan. Pada analisis tersebut dapat dikatakan bahwa penjualan tiket secara online dapat memberikan keuntungan lebih pada perusahaan. Disebutkan pula keunggulan kompetitif stratejik pada cost 
leadership atau diferensiasi sebuah perusahaan digunakan untuk mengetahui posisi perusahaan secara lebih tepat.

\section{METODE}

Terdapat banyak model analisis yang dapat digunakan dalam menganalisis sistem informasi diantaranya analisis porter, chain analysis dan Competitive Forces and Strategy. Porter menggunakan model Five Forces untuk menganalisis. Competitive Forces and Strategy menggunakan lima aspek Competitive Forces dan enam aspek Competitive Strategy.

Model analisis yang digunakan pada sistem informasi Padiciti mencakup konsep Competitive Forces and Strategy. Berikut ini Gambar 2. Menampilkan sub bagian Competitive Forces and Strategy:

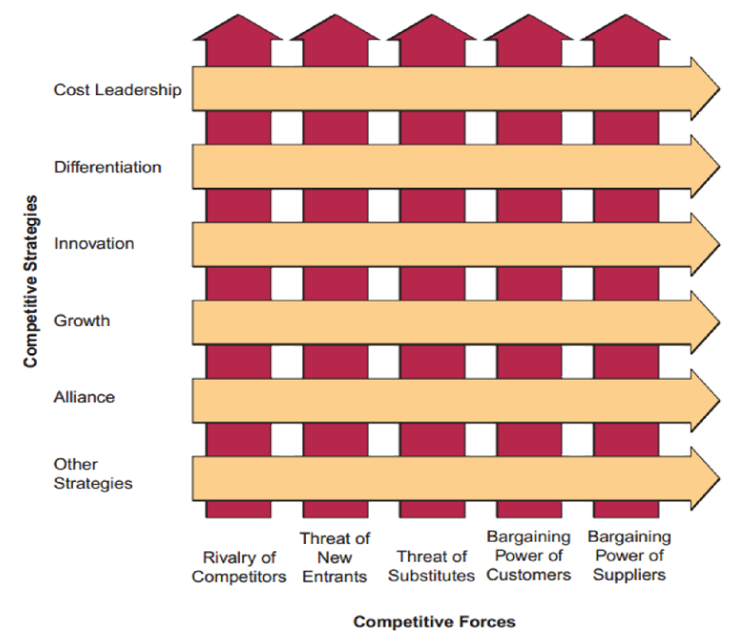

Gambar 2. Competitive Forces and Strategy

Strategi Kompetitif diantaranya adalah pelopor biaya, perbedaan, inovasi, pertumbuhan, aliansi, dan strategi lain. Sedangkan Kekuatan Kompetitif diantaranya adalah persaingan dengan kompetitor, ancaman pendatang baru, ancaman pengganti, kekuatan customer, dan kekuatan supplier.

Penjelasan dari Wilkinson (2013) mengenai Threat of New Entrants yang menjelaskan aspek yang mempengaruhi tinggi dan rendahnya ancaman pengikut dari kompetitor baru. Tingginya ancaman pengikut dari kompetitor baru dapat terjadi ketika :

- Produk yang tidak memiliki perbedaan

- Nama brand tidak diketahui dengan baik

- Investasi inisial kapital rendah

- Rendahnya perubahan permintaan konsumen

- Tidak memperhatikan kepemillikan teknologi

- Tidak memperhatikan kepemillikan materi

- Tidak memperhatikan peraturan pemerintah Rendahnya ancaman pengikut dari kompetitor baru dapat terjadi ketika :

- Produk yang memiliki perbedaan

- Nama brand diketahui dengan baik

- Tingginya investasi inisial kapital

- Tingginya perubahan permintaan konsumen

- Memperhatikan kepemillikan teknologi

- Memperhatikan kepemillikan materi

- Memperhatikan peraturan pemerintah

Penjelasan dari Hines menunjukkan bahwa dalam melakukan analisis threat of substitutes dengan memperhatikan faktor yang mempengaruhi tinggi dan rendahnya indikasi threat of substitutes dari perusahaan lain. Berikut ini faktor yang mempengaruhi. Threat of substitutes rentan tinggi jika :

- Rendahnya perubahan permintaan konsumen

- Produk pengganti lebih murah dibandingkan produk industri

- Kualitas produk pengganti sama atau lebih dari kualitas produk industri

- Performa pengganti sama atau lebih dari performa produk industri

Threat of substitutes rendah jika :

- Tingginya perubahan permintaan konsumen

- Produk pengganti lebih mahal dibandingkan produk industri

- Kualitas produk pengganti lebih rendah dari kualitas produk industri

- Performa pengganti lebih rendah dari performa produk industri

- Tidak ada produk pengganti yang tersedia

Subjek analisis sistem informasi menggunakan konsep Competitive Forces and Strategy adalah penyedia layanan tiket kereta 
api, pesawat, dan hotel yang dapat diakses multiplatform pada website dan smartphone bernama Padiciti. Pengambilan data dilakukan dengan menggunakan informasi yang tersedia pada website dan playstore Padiciti serta analisis pembanding dengan sistem lain.

\section{HASIL DAN PEMBAHASAN}

Hasil analisis sistem informasi Padiciti dengan menggunakan konsep Competitive
Forces and Strategy dijabarkan dalam penjelasan sebagai berikut :

\section{Competitive Strategies}

Cost Leadership

Padiciti telah memikirkan cost leadership dimana dengan ketersediaan dalam berbagai platform dapat memperoleh customer lebih banyak dan keuntungan yang diperoleh akan lebih besar. Tabel 1 berikut ini menampilkan perbandingan kompatibilitas berbagai platform pada Padiciti dan industri pesaing .

Tabel 1. Perbandingan kompatibilitas platform

\begin{tabular}{lcccc}
\hline \hline Platform & Padiciti & Tiket.com & Traveloka & KAI Access \\
\hline \hline Web & $\sqrt{ }$ & $\sqrt{ }$ & $\sqrt{ }$ & $\sqrt{ }$ \\
Android & $\sqrt{ }$ & $\sqrt{ }$ & $\sqrt{ }$ & $\sqrt{ }$ \\
iOS & $\sqrt{ }$ & $\sqrt{ }$ & $\sqrt{ }$ & $\sqrt{ }$ \\
Blacberry & $\sqrt{ }$ & & & $\sqrt{ }$ \\
Windows Phone & $\sqrt{ }$ & & & \\
\hline \hline
\end{tabular}

Tabel 1 menampilkan perbandingan kompatibilitas platform dimana Padiciti memiliki kompatibilitas yang tinggi dengan menyediakan layanan dalam berbagai platform dibandingkan dengan pesaing penyedia layanan tiket lain. Hal tersebut dapat meningkatkan nilai cost leadership yang membuat posisi perusahan lebih menguntungkan. Padiciti dapat memberikan fasilitas pada konsumen dengan latar belakang cara akses yang berbeda.

\section{Differentiation}

Differensiasi merupakan strategi dalam memberikan penawaran yang berbeda dibandingkan penawaran yang diberikan kompetitor. Padiciti memiliki perbedaan dengan jasa penyedia tiket lainnya dimana padiciti menyediakan waitinglist dan pre-order yang dapat mempermudah customer dalam membeli tiket. Pre-order memberikan layanan kepada customer untuk membeli tiket sebelum waktu pembukaan tiket untuk dapat dibeli. Waitinglist memberikan layanan kepada customer untuk memperoleh tiket yang sudah habis dengan menunggu kemungkinan refund dari customer lain.

Pre-order dan waitinglist menggunakan fitur padipay deposit sehingga setelah data dimasukkan tiket akan dibeli oleh Padiciti untuk customer secara otomatis saat tiket tersedia. Hal tersebut sangat membantu customer pada saat libur panjang dan Hari Raya dimana setiap tahunnya terdapat peningkatan jumlah yang belum setara dengan armada yang memadai. Fitur waitinglist dan pre-order membuat customer tidak perlu merefresh secara terus menerus guna melihat kemungkinan kursi yang kosong untuk dapat melakukan order. Hal tersebut dikarenakan aspek differentiation pada Padiciti yang membuat otomatisasi sistem guna 
melakukan order untuk customer melalui sistem saat kursi tersedia. Para pesaing layanan tiket Padiciti tidak memiliki fitur waitinglist dan pre-order tersebut, sehingga ini merupakan kelebihan yang sangat menguntungkan Padiciti.

\section{Innovation}

Inovasi telah dilakukan Padiciti dimana pembelian tiket kereta api, pesawat dan juga hotel terintegrasi dengan akun yang dapat diakses melalui device milik customer dengan akun yang terhubung. Hal tersebut menjadikan customer dalam mengakses kode booking dapat dilakukan dimana pun tanpa takut data hilang. Selain itu juga terdapat data customer yang tersimpan pada sistem, sehingga tidak perlu melakukan input data berulang kali setiap order. Dengan sekali input seluruh data tersimpan dan juga dapat di-load kembali pada seluruh device yang telah login dengan akun pada Padiciti.

Inovasi merupakan strategi kompetitif dalam persaingan dengan perusahan lain dengan layanan tiket yang serupa. Inovasi menjadi perlu dilakukan guna tetap bertahan pada bidang yang diambil yakni penyedia layanan tiket. Inovasi tersebut tidak dimiliki industri pesaing sehingga dapat menjadi kekuatan Padiciti dalam memberikan pelayanan kepada pelanggan.

\section{Growth}

Padiciti mungkin untuk terus tumbuh dan berkembang, dilihat dari perkembangan yang pernah dilakukan dimana awalnya hanya memberikan pelayanan untuk tiket kereta api. Padiciti kini merambah pada pelayanan tiket untuk pesawat terbang dan juga ketersediaan kamar pada hotel. Partner yang bergabung bersama Padiciti pun dapat terus berkembang lebih banyak lagi sehingga mempermudah pelayanan. Termasuk dalam penambahan fitur baru berupa waiting-list dan pre-order.

Perkembangan Padiciti dimunculkan kepada customer pada menu untuk fitur baru. Fitur baru yang akan diaktifkan, sebelumnya sudah ditampilkan dalam update aplikasi terbaru. Menu pada fitur baru dimasukkan dalam aplikasi, namun belum memiliki fungsi maupun data. Hal tersebut dilakukan sebagai media pengenalan kepada customer sehingga saat fitur baru berfungsi, customer tidak mengalami kebingungan.

Pesaing Padiciti memiliki strategi yang berbeda dengan Padiciti dimana memunculkan menu fitur baru tanpa data dan fungsi tidak dilakukan. Aspek Growth menjadi kekuatan Competitive Strategies pada Padiciti yang lebih unggul dibanding pesaingnya.

\section{Alliance}

Padiciti telah terhubung dengan berbagai sistem lain yang saling berkaitan guna mendapatkan informasi. Hal tersebut membantu customer dalam melakukan pemesanan tiket dan juga ketersediaan kamar pada hotel. Padiciti dalam memberikan layanan ketersediaan tiket terhubung dengan berbagai partner yang memiliki armada dan juga hotel secara langsung.

Pada layanan penyedia tiket untuk maskapai penerbangan, Padiciti bekerjasama dengan perusahan lokal dan internasional. Padiciti terhubung secara host-to-host dengan PT Kereta Api Indonesia. Padiciti juga bekerjasama dengan lebih dari 80.000 hotel.

Pada metode pembayaran, Padiciti terhubung dengan banyak bank dan outlet pembayaran tunai. Berikut ini Gambar 3 menampilkan partner Padiciti yang memberikan layanan dalam pembayaran tiket yang telah dipesan.

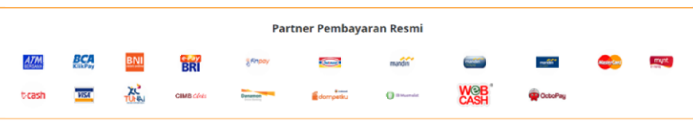

Gambar 3. Partner Pembayaran Resmi

Partner pembayaran resmi tersebut bekerjasama dengan bank dengan layanan berupa e-banking, atm dan juga transfer tunai. Selain itu juga terdapat toko retail online yang dapat memebrikan fasilitas untuk pembayaran tiket melalui Padiciti. 


\section{Other Strategies}

Strategi khusus yang dilakukan Padiciti yaitu memberikan promo dan potongan harga secara langsung pada saat pembayaran tiket. Promo tersebut disesuaikan dengan syarat dan ketentuan yang berlaku. Syarat dan ketentuan dapat berubah sesuai dengan promo yang disediakan.

Promo merupakan strategi yang menarik untuk pelanggan. Promo yang diberikan Padiciti berupa potongan harga untuk layanan tertentu. Potongan harga diberikan berbeda-beda sesuai dengan kerjasama dengan partner yang berbeda setiap periodenya.

\section{Competitive Forces :}

Rivalvy of Competitors

Persaingan merupakan inti dari keberhasilan (Michael E, 1985). Termasuk Padiciti yang juga memiliki pesaing dalam ecommerce penyedia layanan penjualan tiket. Pesaing tersebut diantaranya Tiket.com, Traveloka, KAI Express. Namun, fitur yang diberikan berbeda dengan Padiciti. Persaingan dengan kompetitor yang masih kurang dari Padiciti yaitu pada hal website load speed yang ditampilkan dalam Tabel 2 berikut ini.

Tabel 2. Perbandingan website load speed

\begin{tabular}{|c|c|c|}
\hline Sistem Informasi & \multicolumn{2}{|c|}{ Website Load Speed } \\
\hline \multirow[t]{2}{*}{ Padiciti.com } & Website Favicon: & 0 \\
\hline & Website Load Speed: & $5.7 \mathrm{ses}$ \\
\hline \multirow[t]{2}{*}{ Tiket.com } & Website Favicon: & n \\
\hline & Website Load Speed: & $3.22 \mathrm{se}$ \\
\hline \multirow[t]{2}{*}{ Traveloka.com } & Website Favicon: & $*$ \\
\hline & Website Load Speed: & 1.64 secol \\
\hline
\end{tabular}

Sumber : w3bin.com (2016)

Tabel 2 tersebut memperlihatkan perbandingan waktu load speed dengan pesaing Padiciti. Pada Tabel 2 terlihat bahwa Padiciti memiliki kelemahan dibandingkan dengan pesaing yang memiliki waktu load lebih cepat.
Berikut ini pada Tabel 3 menunjukkan respone time dan rating yang mengidentifikasi waktu yang dibutuhkan pengguna dalam menunggu waktu respon website serta rating penilaiannya.

Tabel 3. Response time dan rating

\begin{tabular}{cc}
\hline \hline Response Time & Rating \\
\hline \hline$<5$ second & High (good) \\
$6-10$ second & Avarage \\
$>10$ second & Low (poor) \\
\hline
\end{tabular}

Sumber: Bouch, Kuchinsky, \& Bhatti

Dengan menggunakan Tabel 3 tersebut dapat diketahui bahwa Padiciti memiliki rating avarage karena memiliki waktu load speed lebih dari 5 second. Dibandingkan dengan pesaingnya yang memiliki rating high (good) karena memiliki waktu load speed kurang dari 5 second.

\section{Threat of New Entrants}

Ancaman dari pengikut dapat terjadi, namun kapasitasnya masih kecil. Padiciti memiliki banyak kelebihan dibandingkan dengan pesaingnya. Kelebihan tersebut telah dijelaskan pada aspek sebelumnya. Threat of new entrants perlu diantisipasi dengan 
peningkatan layanan dan penambahan fitur yang memudahkan pelanggan dalam melakukan transaksi. Peningkatan layanan tersebut harus lebih baik dibandingkan dengan pesaing Padiciti.

Rendahnya Threat of New Entrants dari kompetitor baru terjadi karena Padiciti memiliki :

- Produk yang memiliki perbedaan

- Nama brand diketahui dengan baik

- Tingginya perubahan permintaan konsumen

- Memperhatikan kepemillikan teknologi

- Memperhatikan kepemillikan materi

- Memperhatikan peraturan pemerintah

\section{Threat of Substitutes}

Ancaman pengganti dapat diperoleh dari pesaing Padiciti jika kelemahan Padiciti tidak diantisipasi dengan cepat. Bergantungnya sistem informasi Padiciti terhadap internet, pelanggan dapat berganti kepada aplikasi pesaing jika layanan Padiciti lambat atapun tidak dapat diakses sama sekali. Sistem informasi online perlu memperhatikan waktu load page yang cepat dengan memperhatikan hosting website yang baik pula. Hal tersebut berpengaruh pada saat customer melakukan order menggunakan Padiciti.

Analisis threat of substitutes dengan memperhatikan faktor yang mempengaruhi tinggi dan rendahnya indikasi threat of substitutes dari perusahaan lain. Berikut ini faktor yang mempengaruhi. Threat of substitutes rentan tinggi dikarenakan :

- Kualitas produk pengganti sama atau lebih dari kualitas produk Padiciti

- Performa pengganti lebih dari performa produk Padiciti

\section{Bargaining Power of Customers}

Kekuatan customers dalam menggunakan sistem dimana perubahan dari sistem satu ke sistem yang lainnya terasa lebih mudah. Dimana fitur yang ditampilkan dari website dan aplikasi pada smartphone memiliki kesamaan sehingga customers tidak merasa kesulitan dalam berpindah pindah platform. Ulasan dari
Google menunjukkan Padiciti lebih banyak diminati dibandingkan dengan Tiket.com

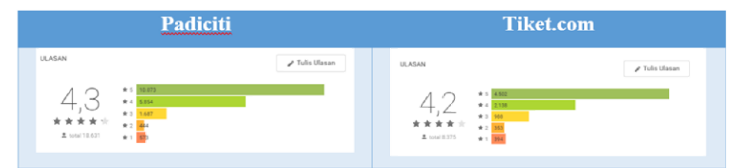

Sumber : (Google, Inc, 2016)

Padiciti memiliki keunggulan dibandingankan dengan pesaingnya dimana ulasan pada Google Play menunjukkan 4,3 dan pesaingnya 4,2. Padiciti sangat interaktif, karena memberikan banyak informasi yang sangat mudah untuk dipelajari bagi pengunjung baru, seperti pada Gambar 4 berikut ini.

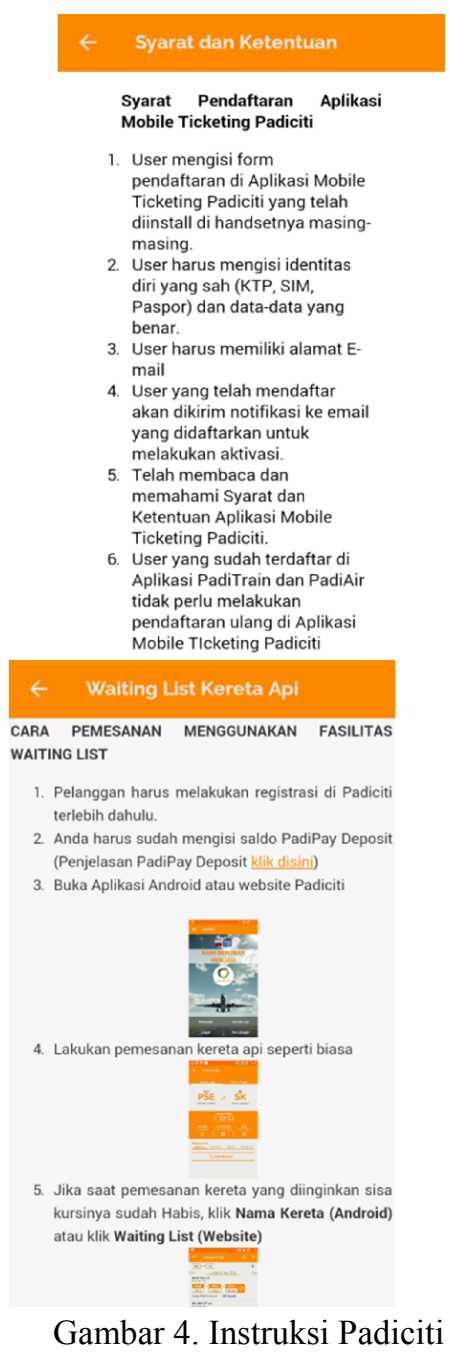

\section{Bargaining Power of Suppliers}

Setiap industri memiliki supplier dalam mendukung penyediaan produk untuk industri. 
Termasuk juga Padiciti yang memiliki supplier dimana partner resmi Padiciti mendukung Padiciti dalam menyediakan tiket pesawat terbang dan juga ketersediaan kamar pada hotel.

Kekuatan suppliers dalam menggunakan sistem Padiciti yaitu perusahaan yang menjadi partner dapat terus memberikan layanan terbaik kepada customer melalui Padiciti. Padiciti juga dapat memberikan banyak pilihan dengan banyaknya partner yang bergabung.

Semakin banyak partner yang bergabung semakin banyak pula pilihan yang diberikan kepada customer. Selain itu juga semakin banyak tiket yang terjual yang memeberikan keuntungan pada supplier penyedia tiket masing-masing.

\section{SIMPULAN}

Kesimpulan yang dapat diambil dari analisis sistem informasi Padiciti dengan menggunakan metode Competitive Forces and Strategy adalah sebagai berikut :

1. Padiciti telah memenuhi Strategi Kompetitif dengan baik dimana cost leadership telah dipikirkan, terdapat perbedaan, terdapat inovasi, memungkinkan untuk tumbuh, terhubung dengan sistem lain dan juga memiliki strategi khusus yang tidak ada pada kriteria sebelumnya.

2. Padiciti telah memenuhi Tantangan Kompetitif dimana kemungkinannya kecil terjadi pada Threat of New Entrants, Bargaining Power of Customers, dan Bargaining Power of Suppliers dapat terus ditingkatkan.

3. Padiciti memiliki aspek yang lemah pada Rivalvy of Competitors dan Threat of Substitutes.

\section{DAFTAR RUJUKAN}

F. Mintarsih, R. Bahawarez dan S. U. Fauziah, "Analisis Perancangan Aplikasi MObile
Commerce Tiket Travel (M-Ticketing) Pada Smartphone Android (Studi Kasus : Travel Umabara Trans)," Jurnal Informatika Vol. 7 No.2 Oktober 2014, 2014.

J. A. O'Brien dan G. M. Marakas, Introduction to Information Systems, McGraw-Hill: New York, 2009.

Google, Inc, "Ulasan," Google Play, 2016. W. Kuntjoroadi dan N. Safitri, "Analisis Strategi Bersaing dalam Persaingan Usaha Penerbangan Komersial," Bisnis \& Birokrasi, Jurnal Ilmu Administrasi dan Organisasi, Jan-Apr 2009, hlm. 45-52, Vol. \%1 dari \%2Volume 16, Nomor 1, 2009.

P. Michael E, Competitive Advantage: creating and sustaining superior performance, New York: The Free Press, 1985.

w3bin.com, "Who is hosting that website?," 2016.

M Suyanto, Strategi Periklanan pada ECommercePerusahaan Top Dunia, Yogyakarta: Penerbit Andi, 2003.

A. Nugroho, E-Commerse Memahami Perdagangan Modern di Dunia Maya, Bandung: Informatika, 2006.

D. Quthni, Terminology E-commerce, 2006.

O. W. Purbo dan A. A. Wahyudi, Mengenal Ecommerce, Jakarta: PT. Elex Media Komputindo, 2001.

Rasmila, "Analisis Strategis Web E-Commece dengan Metode Value Chain Analysis (Studi Kasus PT. Sriwijaya Optimis Mandiri)," Universitas Darma Palembang, Palembang, 2016.

J. Wilkinson, "Threat of New Entrants (one of Porter's Five Forces)," 2014 Juli 2013.

J. Hines, "Threat of Subsětutes (one of Porter's Five Forces)," 24 Juli 2013.

A. Bouch, A. Kuchinsky dan N. Bhatti, "Quality is in the Eye of the Beholder: Meeting Users' Requirements for Internet Quality of Service," CHI, pp. 297-304, 2000. 